\title{
The fate of nucleic acids in ruminants
}

\section{By A. B. McAllan, National Institute for Research in Dairying, Shinfield, Reading, Berkshire RG2 gAT}

Ruminants may ingest appreciable quantities of nucleic acids and large amounts are synthesized by the microbial population in the reticulo-rumen. The importance of nucleic acids to the nutrient intake of the ruminant is probably dependent on the amounts of these materials relative to other nitrogenous substances which are presented to the small intestine. These amounts bear little or no relationship to the dietary intake of nucleic acids but appear to be derived predominantly from microbial synthesis in the rumen. Additional degradative and synthetic processes undoubtedly occur in the omasum but there is little information on this subject. There is also little direct information on possible nucleic acid degradation in the abomasum of the ruminant, although net changes between the reticulo-rumen and duodenum of sheep and steers appear to be small (Smith \& McAllan, I97 I ; Jackson et al. 1976$)$.

\section{Nucleic acids entering the rumen and their digestion}

By far the major source of nucleic acids entering the rumen is the diet. Variable amounts of nucleic acids are present in the most commonly used ruminant feedstuffs ranging from $\mathrm{I}-5^{\circ} \mathrm{g} / \mathrm{kg}$ dry matter (DM). As proportions of the total nitrogen content, nucleic acid- $\mathrm{N}$ has been reported to be $0.0 \mathrm{r}-0.04$ in cereals and protein concentrates, $0.08-0.11$ in hays, $0.05-0.15$ in grasses, $0.13-0.19$ in straws and as much as $0.15-0.25$ in legumes (Goswani \& Wilcox, 1969; McArthur \& Miltimore, I969; Smith \& McAllan, I970; Coehlo da Silva, Seeley, Beever et al. I 972 ; Coehlo da Silva, Seeley, Thomson et al. 1972; A. B. McAllan \& R. H. Smith, unpublished observations). Some forages also contain small amounts of free purines, allantoin and uric acid (Ferguson \& Terry, 1954; Tracey, 1955). Ruminants may therefore consume appreciable amounts of nucleic acids or their degradation products.

Mucosal secretions and sloughed mucosal cells would also contribute to the nucleic acids entering the rumen but the amounts are probably quite small.

When free RNA or DNA were fed to ruminating lambs, little or none survived to the abomasum (Razzaque \& Topps, I 972) and when these compounds were introduced into the rumens of young steers they were rapidly degraded with the transient appearance of small amounts of oligonucleotides, nucleosides and bases (McAllan \& Smith, I973a). These derivatives disappeared from the rumen much more rapidly than could be accounted for by transfer to the lower digestive tract. Similar, though somewhat slower, degradation was observed on anaerobic incubation in vitro with rumen contents from cows, sheep and steers (McAllan \& Smith, r $973^{a}, 1973^{b}$ ). It was found that RNA was degraded within $\mathrm{r} h$ with an initial accumulation of oligo- and mononucleotides, nucleosides and bases. After 
$4 \mathrm{~h}$ only the bases xanthine, hypoxanthine and uracil remained. DNA was similarly, but more slowly, degraded with appreciable amounts of oligo- and mononucleotides surviving after $4^{\mathrm{h}}$ together with the bases xanthine, hypoxanthine, uracil and thymine. Degradation patterns were similar irrespective of the diet of the animals from which the rumen digesta was obtained. Generally, similar results were reported for RNA and DNA breakdown in vitro in rumen contents from buffalo bulls (Sinha \& Dutta, 1980) although these authors found that DNA degraded more rapidly and completely than RNA. Differences between animals in the modes of action of rumen nucleases will, to some extent, reflect different mixed microbial populations in the rumens of these animals.

An attempt was made to elucidate the metabolic pathways of nucleic acid degradation in the rumen by studying the degradation of nucleotides, nucleosides and bases incubated anaerobically with rumen contents (McAllan \& Smith, 1973b). It was concluded that degradation to the free bases was always accompanied by deamination of those bases that carried a side amino group. For adenine it appeared that this occurred at the nucleoside stage and resulted in the final liberation of hypoxanthine. Guanine was first liberated and then deaminated to xanthine. Cytosine was converted to uracil, most probably at the nucleotide or nucleoside stage. The free bases detected in the rumen contents (xanthine, hypoxanthine, uracil and thymine) appeared to be more resistant in vitro than in vivo (McAllan \& Smith, $1973 a ; 1973^{b}$ ) but whether this was a result of the bases being more efficiently utilized by bacteria in vivo or to their being absorbed across or metabolized in the rumen wall is not known. Xanthine, hypoxanthine, uracil and thymine have also been shown to be resistant to breakdown by suspensions of washed rumen bacteria (Jurtshuk et al. 1958).

No detailed studies of the enzymes involved in these processes in the rumen have been published. Enzymes capable of degrading both RNA and DNA have been isolated from many species of non-rumen bacteria and details of modes of action and specificities of some have been published (Cantoni \& Davies, 1966). Ribonuclease activity has been reported in rumen contents and the muscosal wall of cattle (Germanyuk, 1964). Extracellular endonucleases, presumably microbial in origin, have been found in cell-free extracts of rumen digesta from calves, sheep, cows and buffaloes (McAllan \& Smith, r $973 b$; Sinha \& Dutta, I980; A. B. McAllan $\&$ R. H. Smith, unpublished observations). There is little direct evidence for rumen bacteria concerning other enzymes likely to be involved in nucleic acid degradation, although the activities clearly exist.

It is obvious that free nucleic acids and derivatives entering the rumen are rapidly degraded and would not contribute to the large amounts of nucleic acids entering the duodenum. However, little direct evidence exists on the fate of ingested dietary nucleic acids which may be protected by association with other resistant cell structures. Appreciable amounts of the nucleic acids in hay were released and degraded fairly rapidly on incubation with rumen contents (McAllan $\&$ Smith, 1973a). Supporting the idea that dietary nucleic acids are released and degraded in the rumen, it has been found that RNA:DNA in the rumen digesta 
were similar to those in samples of mixed rumen bacteria, indicating that nucleic acids present in digesta from the rumen were predominantly microbial in origin (Gaussères \& Fauconneau, I965; Ellis \& Bleichner, 1969; Smith \& McAllan, 1970). However, other studies have shown that nonmicrobial RNA may contribute up to $15 \%$ of the RNA entering the duodenum of young steers receiving approximately equal amounts of hay and concentrates (Smith et al. 1978).

\section{The fate of nucleic acid breakdown products in the rumen}

The fate of the end-products of nucleic acid catabolism in the rumen is to a large extent as yet undetermined. Soluble sugars are generally attacked rapidly in the rumen and, although not directly shown, it seems certain that ribose and deoxyribose will be degraded rapidly on release from nucleic acids (Jarvis, I 668 ). Entodiniomorphid protozoa can incorporate bases (except thymine), nucleosides and nucleotides into their nucleic acids (Coleman, 1979). Some pure cultures of bacteria have been shown to incorporate thymidine into their nucleic acids (Jarvis, 1968 ) but no other information is available on the possible salvage of nucleosides in the rumen. The uptake of intact adenine, guanine and uracil has been shown by both rumen protozoa and bacteria in vitro (Coleman, 1968, 1972; Smith \& Mathur, 1973; Smith et al. 1974) but there would appear to be little opportunity to do so in vivo because of the rapid deamination of derivatives with side amino groups.

Further catabolism of nucleic acid breakdown products has been reported with the formation of $\beta$-alanine from uracil (Van der Horst, 1965), $\beta$ amino-isobutyric acid from thymine, and ammonia, carbon dioxide and acetic acid from xanthine, guanine, hypoxanthine and uric acid (Doetsch \& Jurtshuk, 1957; Jurtshuk et al. 1958). Rumen bacteria can utilize guanine, uracil, xanthine, allantoin and uric acid as sources of carbon and nitrogen for growth (Belasco, 1954; Bentley et al. 1954; Thornsberry \& Wiseman, I 960 ). Uric acid, commonly added to ruminant diets as a non-protein nitrogen source, is degraded via allantoin to glyoxylate and urea before conversion to ammonia (Thornsberry \& Wiseman, I 960).

\section{Origins of microbial nucleic acids}

The nucleic acid contents of bacteria may vary widely for a variety of reasons (Herbert, 196I) and it has been reported that for isolated pure strains of rumen bacteria grown in vitro, RNA protein increased with increasing growth rate (Bergen et al. 1982). However, it appears that mixed rumen bacteria in vivo grow at some depressed growth rate approaching that of the in vitro stationarytransitory phase batch culture preparations (Bergen et al. 1982). Evidence for a slow, steady growth rate of mixed rumen bacteria is found in the small variations observed in their RNA-N:total-N values. For mixed bacteria taken a few hours after giving concentrate/roughage diets to faunated sheep, cows or steers, values for RNA-N:total-N of $0.055-0.109$ have been reported with the majority of values between 0.065 and 0.085 (McAllan \& Smith, 1971; Smith \& McAllan, 1974; Czerkawski, 1976; McMeniman, 1975; Ling \& Buttery, 1978). Values were lower (by approximately $20 \%$ ) about $16 \mathrm{~h}$ after a feed and higher (by approximately 
$30 \%$ ) in animals lacking protozoa (Smith \& McAllan, I974). DNA-N contents of mixed bacteria populations showed greater variation than RNA-N from one population to another. They also showed greater variations between different pure strains of rumen bacteria (Smith, 1969). In one group of experiments for nine samples of mixed bacteria from the rumens of three steers, mean values for RNA$\mathrm{N}$ :total-N with standard errors were $0.077 \pm 0.002$ and for DNA-N:total-N were $0.056+0.005$ (Smith \& McAllan, 1974). For any one population, however, DNA-N showed less diurnal variation than RNA-N and the effect of the presence or absence of protozoa was less (Smith \& McAllan, 1974). Both RNA-N:total-N and DNA-N:total- $\mathrm{N}$ tended to increase with decreasing amounts of nitrogenous nutrients in rumen contents (McAllan \& Smith, 1971).

It is apparent that total amounts of RNA and DNA synthesized in the rumen depend largely upon the amounts of bacterial growth and this is determined by a number of factors. It is unlikely that rumen bacteria would incorporate nucleotides directly (Van Nevel \& Demeyer, I977) and although, as has been mentioned earlier, they may use preformed bases and nucleosides if these are available, it is probable that the majority of bacterial nucleic acid components are synthesized de novo like those in many non-rumen bacteria (Megasnik, I962). When ${ }^{15} \mathrm{~N}$-labelled ammonia was added to the rumens of steers, ${ }^{15} \mathrm{~N}$ enrichment of all the nucleic acid bases (except thymine) rose steadily during the day and reached a peak about io $\mathrm{h}$ after the introduction of the label. Adenine was always more highly enriched than guanine, and cytosine more highly enriched than thymine (Blake, 1980) confirming kñown metabolic pathways found in non-rumen bacteria (Megasnik, I 962).

Ciliate protozoa, in general, are unable to synthesize purines or pyrimidines (Jaffe \& Gutteridge, 1974) or ribose (Coleman, I968). Rumen protozoa can, however, incorporate free adenine, guanine and uracil into their nucleic acids. They have a limited ability to convert adenine to guanine but a greater ability to convert uracil to cytosine (Coleman, 1979). It is probable that rumen protozoal nucleic acids are derived mainly from bacterial nucleic acids. Less information is available on the nucleic acid content of rumen protozoa. RNA-N:total-N in rumen protozoa have been reported to be similar to (Smith, 1969; Czerkawski, I976) and considerably lower than (Ling \& Buttery, 1978; Tamminga, 1978) those found in mixed rumen bacteria.

\section{Recycling of microbial nucleic acids in the rumen}

If bacteria lack nutrients their nucleic acid components as well as protein are degraded (Nath \& Koch, 1971). Such degradation has been shown to occur both for pure strains and for mixed rumen bacteria incubated in rumen contents, even with apparently adequate nutrients present (Jarvis, I968; Smith \& Smith, I977). From such in vitro studies it was estimated for steers given diets of flaked maize and hay that about $30 \%$ of the bacterial nucleic acid synthesized would be degraded in the rumen (Smith \& Smith, 1977). Turnover of protozoal organic matter (presumably including nucleic acids) is also likely to occur in the rumen to an unknown extent (Weller \& Pilgrim, I974). 


\section{Metabolism and digestion in the small intestine}

Little net changes occur in the amounts of nucleic acids between the rumen and duodenum (Ellis \& Bleichner, 1969; Smith \& McAllan, 1971). Nucleic acids entering the duodenum form $15-35 \mathrm{~g} / \mathrm{kg}$ DM (Smith \& McAllan, 1971; McMeniman, 1975) of which approximately $60-70 \%$ is RNA. The majority (about $85 \%$ for young steers receiving hay and concentrate diets) is microbial in origin.

Enzymes which degrade nucleic acids are present in pancreatic secretions (Barnard, r 969) and small intestine mucosa (Nakayama et al. r $98 \mathrm{I}$ ) and pancreatic ribonuclease is particularly abundant in the ruminant (Barnard, 1969). Enzymes likely to be involved in the digestion of nucleic acids in the small intestines of ruminants have been reviewed elsewhere (Armstrong \& Hutton, 1975). Enzymes secreted into the gut lumen include pancreatic ribonuclease $(E C$ 3.1.4.22) and deoxyribonuclease $(E C$ 3.1.4.5) which, together with phosphodiesterases (EC 3.1.4.1; EC 3.1.4.18) eventually degrade RNA and DNA to $3^{\prime}$ - or 5'mononucleotides. Other enzymes have been detected in small intestine tissue and probably function at the gut wall. No specific $3^{\prime}$-nucleotidase $\left(E C C_{3.1 .3 .6)}\right.$ has been reported in ruminants but alkaline phosphatase $(E C$ 3.1.3.1), which has been isolated from calf small intestine (Barman, 1969), can remove phosphate attached to the $\mathrm{C}_{-}{ }^{\prime}$ in single nucleotides. $5^{\prime}-$ Nucleotidase $(E C$ 3.1.3.5) activity has been detected in calf small intestine tissue (Centar \& Behal, 1966) and catalyses the hydrolysis of a number of phosphate esters. No nucleoside-cleaving enzymes have been reported in ruminant intestinal tissue. Calf small intestine is a rich source of adenosine deaminase ( $E C$ 3.5.4.4) (Barman, I969) and indirect evidence also exists for the presence of cytidine deaminase (EC 3.5.4.5) (Christman, I952). Little or no xanthine oxidase ( $E C$ I.2.3.2) could be found in sheep or goat intestine (Morgan, r 926; Al-Khalidi \& Chaglassian, 1965) but appreciable amounts were present in bovine small intestine (Al-Khalidi \& Chaglassian, 1965). Hypoxanthine oxidase ( $E C$ 1.2.3.2) has also been reported in bovine small intestine (Roussos, 1963 ).

Net digestibilities of the largely microbially-derived nucleic acids between the proximal duodenum and distal ileum of sheep and young steers were about 80-90\% for RNA and $75-85 \%$ for DNA (Ellis \& Bleichner, 1969; Condon \& Hatfield, I971; Smith \& McAllan, I971; Coehlo da Silva, Seeley, Beever et al. 1972; Coehlo da Silva, Seeley, Thomson et al. 1972; Jackson et al. 1976; McAllan, 1980). True digestibilities are presumably rather higher than these because some nucleic acid must be added by sloughed cells (or secretions). McAllan (1980) calculated that at least $97 \%$ of the free nucleic acids infused into the small intestine of steers were degraded. In sheep and young steers most of the RNA and DNA entering the proximal duodenum disappeared in the first $25 \%$ of the small intestine (Jackson et al. 1976; McAllan, 1980). In the steers the nucleic acid degradation was accompanied by the transient appearance of adenosine, guanosine and pyrimidine nucleosides (McAllan, 1980). In other experiments with young steers it was shown that of the nucleic acid derivatives infused into the small intestine, adenine, guanine and uracil were completely removed, thymine 
and xanthine to approximately 80 and $95 \%$ and hypoxanthine and cytosine to only $5^{\mathrm{I}}$ and $48 \%$ respectively (McAllan, 1980). The apparent resistance of cytosine to catabolism in the small intestine has also been reported in sheep (Jackson et al. 1976). The nucleosides adenosine and cytidine were also completely removed but were replaced in part by the catabolic products inosine plus hypoxanthine, or cytosine respectively. Other nucleosides were removed to approximately half the extent of the corresponding bases (McAllan, 1980). Adenine and uracil were also shown to be completely absorbed from the small intestines of lambs (Condon et al. 1970; Condon, 197I). It is possible that the conversion of nucleoside to base is a rate-limiting step. Active uptake of some purines and pyrimidines by sheep and lamb jejunal mucosa has been reported (Scharrer \& Amann, 1979, 1980). Hypoxanthine, adenosine, uracil and thymine appear to compete for a common carrier mechanism and uracil uptake was higher in the midthan in the proximal jejunum (Scharrer \& Amann, 1979).

It is known that nitrogen compounds leaving the ileum are attacked by bacteria in the large intestine and it is probable that residual amounts of nucleic acids entering the large intestine are degraded in this way. At the same time bacterial growth in the large intestine is responsible for nucleic acid synthesis and as a net effect one would expect the amounts of nucleic acids to increase in the large intestine. This was found in sheep receiving semi-purified diets (Ellis \& Bleichner, 1969) but not in sheep receiving forage diets (Coehlo da Silva, Seeley, Beever et al. 1972; Coehlo da Silva, Seeley, Thomson et al. 1972). The extent of any bacterial nucleic acid synthesis in the large intestine will depend to a major extent on the energy available. RNA excretion in the faeces of sheep increased when the animals were given starch infusions into the caecum (Mason et al. 1977).

\section{Metabolism of absorbed nucleic acid components and excretion of end-products}

Levels of purine nucleotides in sheep bluvi are similar to those found in other mammals with the main component being adenosine triphosphate (ATP) (Brown et al. 1972). This component, the concentration of which is unlikely to be related to the absorption of nucleic acid components from the gut, is also present in bovine blood but in smaller amounts (Baird, 1966). Bovine blood, however, contains appreciable amounts of uric acid riboside (Smith \& Stricker, 1975, 1976, 1977) which is confined to the erythrocytes (Newton \& Davis, 1922). Concentrations of uric acid riboside in bovine blood are considerably greater than the average levels of free uric acid. This intracellular conversion may be a means of solubilizing uric acid for transport from tissues to kidneys, or it may be involved in the mechanism for transporting uric acid across cell membranes. Foetal bovine blood contains no uric acid riboside and other nucleotide levels are higher than in adult animals (Smith \& Stricker, 1976). Levels of uric acid riboside increase and other nucleotide levels decrease with age, all reaching stable adult values after three months (Smith \& Stricker, 1975). Allantoin and free uric acid are also present in ruminant blood in 
amounts directly related to the nucleic acid concentrations in the rumen and to allantoin and uric acid levels in urine (Kaplan \& Pobirsky, 1974). Infusions of purine bases into the duodenum of steers resulted in related increases in plasma. levels of allantoin (McAllan, 1980). When steers are fasted their plasma allantoin and uric acid levels fall (Kaplan \& Pobirsky, 1974). Glyoxylic acid, a breakdown product of allantoin, occurs in the serum of cattle and sheep in similar concentrations to those found in other mammals (Van der Horst, 1960).

Few studies of enzymes concerned with nucleic acid metabolism have been made in the ruminant (Morgan, I926; Al-Khalidi \& Chaglassian, 1965). Apart from the fact that the bovine contains appreciable amounts of xanthine oxidase in blood, spleen, liver, kidney and intestines, whereas in other animals the enzyme is mainly confined to the liver (Morgan, 1926; Al-Khalidi \& Chaglassian, 1965), there appear to be no major differences, but little comparative work has been done.

There is evidence that some nucleic acid components absorbed from the gut of the animal may be incorporated directly into the animal's nucleic acids. Thus infusions of ${ }^{14} \mathrm{C}$-labelled RNA, adenine and guanine into the abomasums of lambs resulted in $10 \%$ of the radioactivity appearing in tissue nucleic acids (Condon et al. 1970; Condon, 1971). In other experiments, tissue samples from sheep slaughtered $24 \mathrm{~h}$ after bacteria, labelled with ${ }^{14} \mathrm{C}$ in their nucleic acid adenine and guanine, had been infused into the rumen, all contained radioactive nucleic acids (Smith et al. 1974). The highest levels of activity were found in the liver, kidney, spleen and blood. The radioactivity was present only in adenine and guanine, showing direct incorporation rather than degradation and resynthesis. Approximately $5 \%$ of the bacterial nucleic acids were incorporated into liver, kidney and spleen and it was calculated that muscle would contain a further $20 \%$. Further evidence for the salvage of bacterial nucleic acids is supplied by the work of Razzaque $e t$ al. ( $(\mathrm{g} 8 \mathrm{I}$ ) who found that $48 \mathrm{~h}$ after injecting rumen bacteria with $8-{ }^{14} \mathrm{C}$-labelled adenine into the rumen of lambs, approximately $47 \%$ of the absorbed activity was found in the tissues. The highest levels of activity were found in the liver, thymus and pancreas. However, most absorbed nucleic acid components are catabolized and, in most mammals, although a variety of intermediate products may be excreted, the principal nitrogenous end-products are urea from pyrimidines and uric acid and allantoin from purines.

In the ruminant the excretion of allantoin is strongly correlated with the concentrations of nucleic acids in the rumen contents (Topps \& Elliott, 1965; Kaplan \& Pobirsky, 1974) and the amounts of nucleic acids entering the duodenum (Condon \& Hatfield, I97I; Antoniewicz et al. 1980). The amounts of allantoin excreted in the urine have been shown to vary with dietary protein, energy and DM intakes (Nehring et al. 1965; Topps \& Elliott, 1967; Maloiy et al. 1970; Pfeffer et al. 1975; Vercoe, 1976), presumably because of variations in microbial nucleic acid synthesis. Short-term heat exposure has also been shown to increase the endogenous part of the urinary excreted allantoin in calves (El Fouly \& Kamal, 1979). It is of interest that in the deer and to a lesser extent in the sheep, appreciable amounts of hypoxanthine and xanthine are excreted in the urine as 
well as allantoin (Razzaque et al. 1973). Glyoxylic acid is present in cow and sheep urine in appreciably greater amounts than it is in non-ruminant urine (Van der Horst, 1960; Aafjes, 1963).

\section{REFERENCES}

Aafjes, J. H. (1963). Br. Vet. $\mathcal{F} . \times 19,387$.

Al-Khalidi, U. A. S. \& Chaglassian, T. H. (1965). Biochem. $\mathcal{J} .97,318$.

Antoniewicz, A. M., Heinemann, W. W. \& Hanks, E. M. (1980). F. agric. Sci., Camb. $95,395$.

Armstrong, D. G. \& Hutton, K. (1975). In Digestion and Metabolism in the Ruminant, p. 432 [1. W. McDonald and A. C. I. Warner, editors]. Armidale: University of New England Publishing Unit.

Baird, G. D. (1966). Nature, Lond. 2 10, 863.

Barman, T'. (1969). Enzyme Handbook. Berlin: Springer-Verlag.

Barnard, E. A. (1969). Nature, Lond. $221,340$.

Belasco, I. J. (1954). J. Anim. Sci. 13,601.

Bentley, O. G., Johnson, R. R., Vanecko, S. \& Hunt, C. H. (1954). F. Anim. Sci. 13, $5^{81}$.

Bergen, W. G., Bates, D. B., Johnson, D. E., Waller, J. C. \& Black, J. R. (1982). In Protein Requirements for Cattle, p. 99 [F. N. Owens, editor]. Stillwater: Oklahoma State University.

Blake, J. S. ( 1980 ). Studies with ${ }^{15} \mathrm{~N}$ on amino acid metabolism in rumen bacteria. PhD Thesis, University of Reading.

Brown, P. R., Agarwal, R. P., Gell, J. \& Parkes, R. E. Jr (1972). Comp. Biochem. Physiol. 43B, 891 .

Cantoni, G. L. \& Davies, D. R. [editors] (1966). Procedures in Nucleic Acid Research. New York: Harper \& Row.

Centar, M. S. \& Behal, F. J. (1966). Arch. Biochem. Biophys. I 14, 4 I 4 .

Christman, A. A. (1952). Physiol. Rev. 32, 303.

Coehlo da Silva, J. F., Seeley, R. C., Beever, D. E., Prescott, J. H. D. \& Armstrong, D. J. (1972). Br. J. Nutr. 28, 357 .

Coehlo da Silva, J. F., Seeley, R. C., Thomson, D. J., Beever, D. E. \& Armstrong, D. J. (1972). Br. F. Nutr. 28, 43 .

Coleman, G. S. (1 968). F. Gen. Microbiol. 54, 83 .

Coleman, G. S. (1972). F. Gen. Microbiol. 71, I 7 .

Coleman, G. S. (1979). In Biochemistry and Physiology of Protozoa, 2nd ed., p. $3^{81}$ [M. Levandowsky and S. H. Hutner, editors]. New York, London: Academic Press.

Condon, R. J. (1971). Diss. Abstr. int. 32B, 641 .

Condon, R. J., Hall, G. \& Hatfield, E. E. (1970). J. Anim. Sci. 31, 1037.

Condon, R. J. \& Hatfield, E. E. (197I). Fedn. Proc. Fedn. Am. Socs exp. Biol. 30, 402.

Czerkawski, J. W. (1976). F. Sci. Fd Agric. 27,621.

Doetsch, R. N. \& Jurtshuk, P. (1957). Misc. Publs. agric. Exp. Stn. Univ. Md. no. 129, p. 8.

El-Fouly, H. A. \& Kamal, T. H. (1979). Wld. Rev. Anim. Prod. 15, 61.

Ellis, W. C. \& Bleichner, K. L. (1969). Fedn. Proc. Fedn. Am. Socs. exp. Biol. $28,623$.

Ferguson, W. S. \& Terry, R. A. (1954). F. Sci. Fd Agric. 5, 515.

Gaussères, B. \& Fauconneau, G. (1965). Annls. Biol. anim. Biochem. Biophys. 5, 5.

Germanyuk, Y. L. (1964). Fiziol. i. Biokhim Sil's'kogospodii Tvarin, 2, 17.

Goswani, A. K. \& Wilcox, J. S. (1969). F. Sci. Fd Agric. 20, 596.

Herbert, D. (1965). In Microbial Reaction to the Environment, i th Symp. Soc. Gen. Microb., p. 39 I [G. G. Meynell and H. Gooder, editors]. Cambridge: Cambridge University Press.

Jackson, T. C., Schelling, G. T., Mitchell, G. E. \& Tucker, R. E. (1976). Э. Anim. Sci. 43, 325.

Jaffe, J. J. \& Gutteridge, W. E. (1974). Actual Protozool. 1, 23.

Jarvis, B. D. W. (1968). Appl. Microbiol. 16, 714.

Jurtshuk, P. Jr, Doetsch, R. N. \& Shaw, J. C. (1958). F. Dairy Sci. 41, 190.

Kaplan, V. A. \& Pobirsky, N. N. (1974). Skh. Biol. 9, 91.

Ling, J. R. \& Buttery, P. J. (1978). Br. F. Nutr. 39, I65.

McAllan, A. B. ( I 980). Br. F. Nutr. 44, 99. 


\section{Vol. 4I New protein sources and nucleic acid metabolism}

McAllan, A. B. \& Smith, R. H. (1971). Proc. Nutr. Soc. 31, 24 A.

McAllan, A. B. \& Smith, R. H. (1973a). Br. F. Nutr. 29, 331.

McAllan, A. B. \& Smith, R. H. (1973b). Br. F. Nutr. 29, 467.

McArthur, J. M. \& Miltimore, J. E. (1969). Can. J. Anim. Sci. 49, 69.

McMeniman, N. P. (1975). Aspects of nitrogen digestion in the ruminant. PhD Thesis, University of Newcastle-upon-Tyne.

Maloiy, G. M. O., Kay, R. N. B., Goodall, E. D. \& Topps, J. H. (1970). Br. F. Nutr. 24, 843.

Mason, V. C., Narang, M. P., Ononiwu, J. C. \& Kessank, P. (1977). Proc. and Internat. Symp. Protein Metab., The Netherlands, p. 6r. Wageningen: Centre for Agricultural Publishing and Documentation.

Megasnik, B. (1962). In The Bacteria, vol. III, ch. 6 [I. C. Gunsalus and R. Y. Stannier, editors]. New York, London: Academic Press.

Morgan, E. J. (1926). Biochem. F. 20, 1282.

Nakayama, J., Fujiyoshi, T., Nakamura, M. \& Anai, M. (1981). f. biol. Chem. 266, 1636.

Nath, K. \& Koch, A. L. (197I). F. biol. Chem. 246, 6956.

Nehring, K., Zelck, U. \& Schiemann, R. (1965). Arch Tierernähr. 15, 45.

Newton, E. R. \& Davis, A. R. (1922). $\mathscr{f}$. biol. Chem. 54, 601.

Pfeffer, E., Klapsing, J. \& Besecke, C. (1975). Z. Tierphysiol. Tierernähr. Futtermittelk, 35, 101.

Razzaque, M. A. \& Topps, J. H. (1972). Proc. Nutr. Soc. 31, 105A.

Razzaque, M. A., Topps, J. H., Goodall, E. D. \& Kay, R. N. B. (1973). Proc. Nutr. Soc. 32, 59A.

Razzaque, M. A., Topps, J. H., Kay, R. N. B. \& Brockway, J. M. (I981). Br. F. Nutr. 45, $5^{1} 7$.

Roussos, G. G. ( 1963 ). Biochim. Biophys. Acta 73, $33^{8}$.

Scharrer, E. \& Amann, B. (1979). Ann. Rech. Vet. 10, 467.

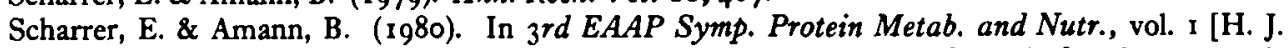
Oslage and K. Rohr, editors]. Braunschweig: Information Centre of Bundesforschungsanstalt für Landwirtschaft.

Scharrer, E., Raab, W., Tiemeyer, W. \& Amann, B. (1981). Pflugers Arch. 39 r, 4 I.

Sinha, P. R. \& Dutta, S. M. (1980). In Protein and NPN Utilization in Ruminants [B. N. Gupta and S. P. Arora, editors]. Karnal: NDRI Press.

Smith, R. C. \& Mathur, C. F. (1973). Can. F. Microbiol. 19, 591.

Smith, R. C., Moussa, N. M. \& Hawkins, G. E. (1974). Br. Y. Nutr. 32, 529.

Smith, R. C. \& Smith, R. H. (1977). Br. F. Nutr. 37, $3^{89}$.

Smith, R. C. \& Stricker, C. M. (1975). F. Anim. Sci. 41, 1674.

Smith, R. C. \& Stricker, C. M. (1976). Int. F. Biochem. 7, 479.

Smith, R. C. \& Stricker, C. M. (1977). Biochem. Biophys. Res. Commun. 76, 559.

Smith, R. H. (1 969). F. Dairy Res. 36, 313 .

Smith, R. H. \& McAllan, A. B. (1970). Br. J. Nutr. 24, 545.

Smith, R. H. \& McAllan, A. B. (1971). Br. F. Nutr. 25, 181 .

Smith, R. H. \& McAllan, A. B. (1974). Br. F. Nutr. 31, 27.

Smith, R. H., McAllan, A. B., Hewitt, D. \& Lewis, P. E. (1978). F. agric Sci., Camb. 90, 557.

Tamminga, S. (1978). In Ruminant Digestion and Feed Evaluation, section no. 5.I [D. F. Osbourn, D. E. Beever and D. J. Thomson, editors]. London: ARC.

Thornsberry, C. \& Wiseman, R. F. (I 960). Bacteriol. Proc. 32.

Topps, J. H. \& Elliott, R. C. (1965). Nature, Lond. 205, 498.

Topps, J. H. \& Elliott, R. C. (1967). Anim. Prod. 9, 219.

Topps, J. H., Goodall, E. D., Kay, R. N. B. \& Maloiy, G. M. O. (1968). Proc. Nutr. Soc. 27, 53A.

Tracey, M. V. (I955). In Moderne Methoden der Pflanzenalyse, p. I 9 [K. Paech and M. V. Tracey, editors]. Berlin: Springer-Verlag.

Van der Horst, C. J. G. (1960). Nature, Lond. 187, 146.

Van der Horst, C. J. G. (1965). Tijdschr. Diergeneesk. 90, $36 \mathrm{I}$.

Van Nevel, C. J. \& Demeyer, D. I. (1977). Br. F. Nutr. 38, 101.

Vercoe, J. E. (1976). F. agric. Sci., Camb. 86, 613.

Weller, R. A. \& Pilgrim, A. F. (1974). Br. F. Nutr. 32, 34 I. 